\title{
ZnO/CuSCN Nano-Heterostructure as a Highly Efficient Field Emitter: a Combined Experimental and Theoretical Investigation
}

Prashant K. Baviskar, "I Sachin R. Rondiya, "I Girish P. Patil, Babasaheb R. Sankapal, Habib M. Pathan, Padmakar G. Chavan, and Nelson Y. Dzade*

Cite This: ACS Omega 2020, 5, 6715-6724

Read Online

ABSTRACT: We report the synthesis of two-dimensional porous $\mathrm{ZnO}$ nanosheets, $\mathrm{CuSCN}$ nanocoins, and $\mathrm{ZnO} / \mathrm{CuSCN}$ nano-heterostructure thin films grown on fluorine-doped tin oxide substrates via two simple and low-cost solution chemical routes, i.e., chemical bath deposition and successive ionic layer adsorption and reaction methods. Detail characterizations regarding the structural, optoelectronic, and morphological properties have been carried out, which reveal high-quality and crystalline synthesized materials. Field emission (FE) investigations performed at room temperature with a base pressure of $1 \times$ $10^{-8}$ mbar demonstrate superior FE performance of the $\mathrm{ZnO} / \mathrm{CuSCN}$ nanoheterostructure compared to the isolated porous $\mathrm{ZnO}$ nanosheets and $\mathrm{CuSCN}$ nanocoins. For instance, the turn-on field required to draw a current density of $10 \mu \mathrm{A} / \mathrm{cm}^{2}$ is found to be $2.2,1.1$, and $0.7 \mathrm{~V} / \mu \mathrm{m}$ for the $\mathrm{ZnO}, \mathrm{CuSCN}$, and $\mathrm{ZnO} / \mathrm{CuSCN}$ nano-heterostructure, respectively. The observed significant

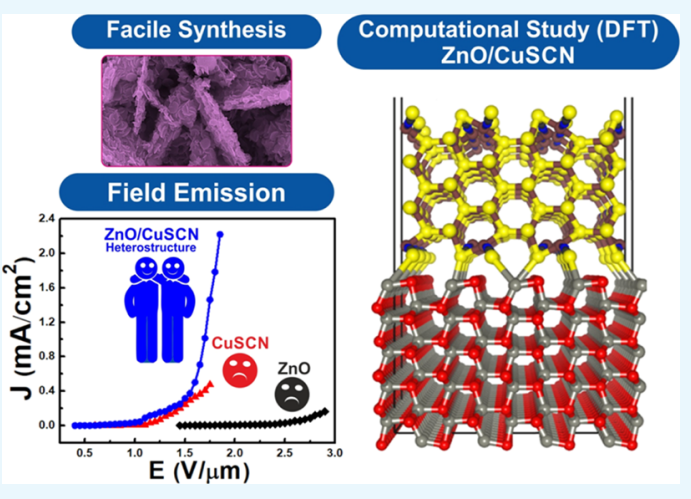
improvement in the FE characteristics (ultralow turn-on field of $0.7 \mathrm{~V} / \mu \mathrm{m}$ for an emission current density of $10 \mu \mathrm{A} / \mathrm{cm}^{2}$ and the achieved high current density of $2.2 \mathrm{~mA} / \mathrm{cm}^{2}$ at a relatively low applied electric field of $1.8 \mathrm{~V} / \mu \mathrm{m}$ ) for the $\mathrm{ZnO} / \mathrm{CuSCN}$ nano-heterostructure is superior to the isolated porous $\mathrm{ZnO}$ nanosheets, CuSCN nanocoins, and other reported semiconducting nano-heterostructures. Complementary first-principles density functional theory calculations predict a lower work function for the $\mathrm{ZnO} / \mathrm{CuSCN}$ nano-heterostructure $(4.58 \mathrm{eV})$, compared to the isolated $\mathrm{ZnO}$ $(5.24 \mathrm{eV})$ and $\mathrm{CuSCN}(4.91 \mathrm{eV})$, validating the superior FE characteristics of the $\mathrm{ZnO} / \mathrm{CuSCN}$ nano-heterostructure. The $\mathrm{ZnO} /$ $\mathrm{CuSCN}$ nanocomposite could provide a promising class of FE cathodes, flat panel displays, microwave tubes, and electron sources.

\section{INTRODUCTION}

Contrary to bulk materials, the bottom-up approach of nanotechnology enables us to engineer the physical behavior of materials significantly away from their intrinsic bulk properties. ${ }^{1}$ Our ability to manipulate materials at the nanoscale has opened the possibility to realize nanoheterostructures that combine and modify the properties of nanomaterials. Nanoscale heterostructures of different material compositions have shown great promise in enhancing the efficiency and functionality of optoelectronic devices owing to the fact that the desirable physicochemical attributes of the participating materials complement each other. A variety of nanofabrication techniques now exist for the synthesis of onedimensional (1D) and two-dimensional (2D) nanostructures to be employed in optoelectronic devices. ${ }^{2-6}$ Among them, 1D and $2 \mathrm{D} \mathrm{ZnO}$ nanostructures ${ }^{7-14}$ are attractive earth-abundant and nontoxic materials with ideal physicochemical and optoelectronic properties for a wide range of functional applications, including but not limited to photocatalysts, ${ }^{15,16}$ gas sensors, ${ }^{17,18}$ and many optoelectronic devices such as field electron emitters, ${ }^{11,19,20}$ photodiodes, ${ }^{21}$ blue light-emitting diodes, $^{22}$ and solar cells. ${ }^{23}$
Heterogeneous deposition on highly structured semiconductor substrates such as $\mathrm{ZnO}, \mathrm{TiO}_{2}$, and $\mathrm{GaN}$ to form heterojunctions has received great scientific interests in recent years for applications in electronic, photoelectrical, field emission (FE), and catalytic applications, where interface area enlargement is generally desirable. ${ }^{24,25}$ Compared to other semiconductor materials, $\mathrm{ZnO}$ displays several advantages owing to its large exciton binding energy $(60 \mathrm{meV})$, wider energy gap $(3.37 \mathrm{eV})$, efficient photon emission at room temperature, high thermal stability, robust mechanical strength, and inertness to high energy radiation. There exists significant literature about the synthesis of various shapes and forms of nano-structured $\mathrm{ZnO}$ such as nanobeads, ${ }^{26}$ nanowires, ${ }^{27}$ nanobelts, ${ }^{28}$ nanorods, ${ }^{29}$ nanotubes, ${ }^{30}$ and nanosheets. ${ }^{31}$ Compared to its flat films, by fabricating $\mathrm{ZnO}$ hetero-

Received: January 1, 2020

Accepted: February 25, 2020

Published: March 20, 2020 
junctions, ${ }^{32-35}$ the interface area can be significantly enlarged by a factor of $10-100 .^{36} \mathrm{ZnO}$-based $\mathrm{p}-\mathrm{n}$ heterojunctions have therefore been examined for light-emitting and UV photovoltaic cells, gas sensors, electroluminescence, and photoresponse characteristics.

$\mathrm{ZnO}$-based heterojunctions are also attractive for $\mathrm{FE}$ applications, where electrons are extracted from the surface of a metal/semiconductor by an electrostatic field through quantum mechanical tunneling. The emission of electrons from the surface of materials is of significant interest to a wide area of applications including the use in telecommunication satellites, medical devices, space research, X-ray sources, electronic displays, electron microscopes, and cathode-ray tube monitors. 8,9 The properties that are desirable for efficient field emitter materials include a stable surface work function, excellent thermomechanical properties, and the capability to achieve high aspect structures to enable operation at low applied fields. A good field emitter must also achieve low turnon field and high emission current density that is stable over a long period of time. Heterostructure designs have recently been shown as an effective strategy for improving the turn-on field of emitter materials. ${ }^{18-20}$ Young and $\mathrm{Lai}^{37}$ reported an enhancement in FE properties $\mathrm{ZnO}$ nanorods after UV illumination and $\mathrm{Au}$ nanoparticle coating. Drastic improvement in the current density of $\mathrm{ZnO}$ nanopillars has also been achieved by Chang et al. ${ }^{38}$ through surface modification with gold nanoparticles. Superior FE properties were also reported for layered $\mathrm{WS}_{2}$-RGO nanocomposites. ${ }^{39}$

Copper thiocyanate $(\mathrm{CuSCN})$, an inorganic p-type semiconductor, is a promising heterojunction partner for $\mathrm{ZnO}$ to achieve enhanced FE characteristics because of its transparency in the visible light spectrum range, ${ }^{40}$ large direct bandgap (3.9 $\mathrm{eV})$, high hole mobility $\left(\geq 5 \times 10^{-4} \mathrm{~S} \mathrm{~cm}^{-1}\right),{ }^{41}$ excellent chemical stability, nontoxicity, and low cost. ${ }^{42}$ Owing to their large bandgap, devices made of $\mathrm{ZnO}$ and $\mathrm{CuSCN}$ are also suitable for preparing transparent optoelectronic devices. ${ }^{43}$ Although fabricated $\mathrm{ZnO} / \mathrm{CuSCN}$ nanorod-based $\mathrm{p}-\mathrm{n}$ heterojunctions have exhibited improved efficiencies in photovoltaic devices, ${ }^{44,45}$ it has not yet been exploited for FE application.

In this study, we report a simple and yet very effective lowtemperature method for fabricating the $\mathrm{ZnO} / \mathrm{CuSCN}$ nanoheterostructures for $\mathrm{FE}$ application. By decorating the porous $\mathrm{ZnO}$ nanosheets with $\mathrm{CuSCN}$ nanocoins, significant improvements in FE characteristics were observed (ultralow turn-on field of $0.7 \mathrm{~V} / \mu \mathrm{m}$ for an emission current density of $10 \mu \mathrm{A} /$ $\mathrm{cm}^{2}$ ). Our results were corroborated through first-principles density functional theory (DFT) analyses, which predict lower work functions for the $\mathrm{ZnO} / \mathrm{CuSCN}$ heterostructure compared to the isolated $\mathrm{ZnO}$ and $\mathrm{CuSCN}$ as the primary origin for the improved FE. These findings demonstrate that the rational design of nanoscale heterostructures can be used as an effective strategy to drastically enhance the FE characteristics, such as the turn-on and threshold electric fields and emission current density.

\section{RESULTS AND DISCUSSION}

2.1. Structural and Compositional Analyses. X-ray diffraction (XRD) patterns of the $\mathrm{ZnO}, \mathrm{CuSCN}$, and $\mathrm{ZnO} /$ $\mathrm{CuSCN}$ nano-heterostructure films are shown in Figure 1a. The porous $\mathrm{ZnO}$ nanosheets are characterized by well-defined diffracted peaks [pattern (a)] with strong orientations along (100), (002), and (101) planes, showing the polycrystalline nature of the porous $\mathrm{ZnO}$ film. All aforesaid peaks were
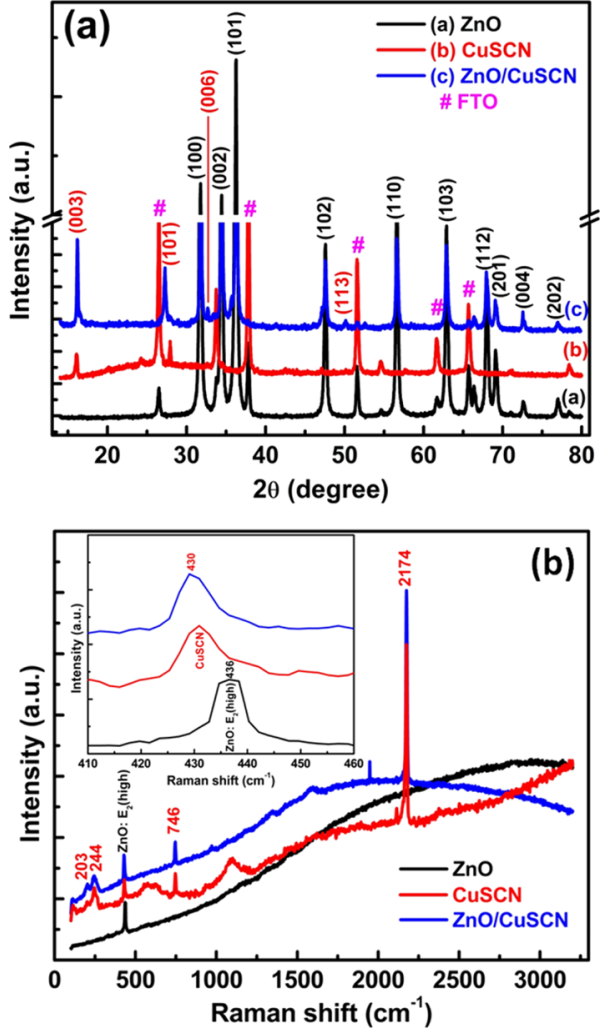

Figure 1. (a) X-ray diffraction pattern and (b) Raman spectra of $\mathrm{ZnO}$, $\mathrm{CuSCN}$, and $\mathrm{ZnO} / \mathrm{CuSCN}$ heterostructure films.

assigned to the wurtzite structure showing the hexagonal phase for $\mathrm{ZnO}$ (JCPDS file no. \# 36-1451). The XRD pattern of $\mathrm{CuSCN}$ as depicted in pattern (b) reveals strong diffraction peaks for the (003) and (101) planes, which can be indexed to the rhombohedral structure (JCPDS card no. \# 29-0581). ${ }^{46}$ The XRD pattern for $\mathrm{ZnO} / \mathrm{CuSCN}$ as shown in pattern (c) represents the combination of two sets of patterns: one from porous $\mathrm{ZnO}$ nanosheets and other derived from the $\mathrm{CuSCN}$ nanocoins. Thus, the formation of the nano-heterostructure $\mathrm{ZnO} / \mathrm{CuSCN}$ is confirmed from the XRD pattern. The symbol (\#) shown in the XRD pattern is assigned to the peaks arising from the fluorine-doped tin oxide (FTO)-coated glass substrate.

Figure $1 \mathrm{~b}$ shows the Raman spectra of the $\mathrm{ZnO}$ nanosheets, $\mathrm{CuSCN}$ nanocoins, and $\mathrm{ZnO} / \mathrm{CuSCN}$ nano-heterostructures, with the spectra referenced by the $S i 521 \mathrm{~cm}^{-1}$ peak. Before the deposition of $\mathrm{CuSCN}$, one sharp peak corresponding to the E2 (high) mode of hexagonal $\mathrm{ZnO}$ is observed at $436 \mathrm{~cm}^{-1}$. 47 The highly intense peak at $2174 \mathrm{~cm}^{-1}$ is observed in the Raman spectra of CuSCN, which can be assigned to the characteristic stretching $\mathrm{C} \equiv \mathrm{N}$ bonds, whereas the peak at $430 \mathrm{~cm}^{-1}$ (the inset of Figure $1 \mathrm{~b}$ ) corresponds to the $\mathrm{SCN}$ group bending. Another sharp peak at $746 \mathrm{~cm}^{-1}$ is noticed, which corresponds to the $\mathrm{C}-\mathrm{S}$ bond stretching. Finally, the wide doublet of two peaks at 203 and $244 \mathrm{~cm}^{-1}$ can be assigned to the $\mathrm{Cu}-\mathrm{S}$ and $\mathrm{Cu}-\mathrm{N}$ stretching, respectively. ${ }^{48}$ After the deposition of $\mathrm{CuSCN}$ over $\mathrm{ZnO}$, one can observe that the $\mathrm{ZnO}$ peak at $436 \mathrm{~cm}^{-1}$ exhibits an inhomogeneous broadening, indicating the presence of the CuSCN nanocoins (inset). In the Raman spectra, the broad peaks in the CuSCN sample at around 550 and $1100 \mathrm{~cm}^{-1}$ arises because of the background signal. Similar Raman peaks were observed in the synthesized 2D CuSCN 
films and $400 \mathrm{~nm}$ nanowire CuSCN samples with peaks appearing at 563 and $1100 \mathrm{~cm}^{-1}$ attributed to the background signal. ${ }^{49,50}$ The Raman spectrum of the $\mathrm{ZnO} / \mathrm{CuSCN}$ nanoheterostructure film has a lower signal-to-noise ratio compared to that from pristine porous $\mathrm{ZnO}$ nanosheets and $\mathrm{CuSCN}$ nanocoins. This may be because of the increase in surface roughness after decoration of $\mathrm{CuSCN}$ nanocoins over the porous $\mathrm{ZnO}$ nanosheets, providing further evidence of $\mathrm{ZnO}$ / $\mathrm{CuSCN}$ nano-heterostructure formation. Besides, our energydispersive X-ray spectroscopy (EDS) composition analysis of the $\mathrm{ZnO} / \mathrm{CuSCN}$ film (Supporting Information, Figure S1a) demonstrates the presence of $\mathrm{Zn}$ and $\mathrm{O}$ elements along with $\mathrm{Cu}, \mathrm{S}, \mathrm{C}$, and $\mathrm{N}$, confirming the formation of the $\mathrm{ZnO} /$ $\mathrm{CuSCN}$ heterostructure. The average atomic \% of $\mathrm{Zn}, \mathrm{O}, \mathrm{Cu}$, $\mathrm{S}, \mathrm{C}$, and $\mathrm{N}$ is tabulated in the inset of Figure S1a. The crosssectional EDS mapping of the $\mathrm{ZnO} / \mathrm{CuSCN}$ nano-heterostructure films (Supporting Information, Figure S1b) clearly depicts the decoration of higher concentration of $\mathrm{CuSCN}$ over the top of the porous $\mathrm{ZnO}$ nanosheets.

2.2. Surface Morphological Analyses. Figure 2 depicts the field emission scanning electron microscopy (FESEM)

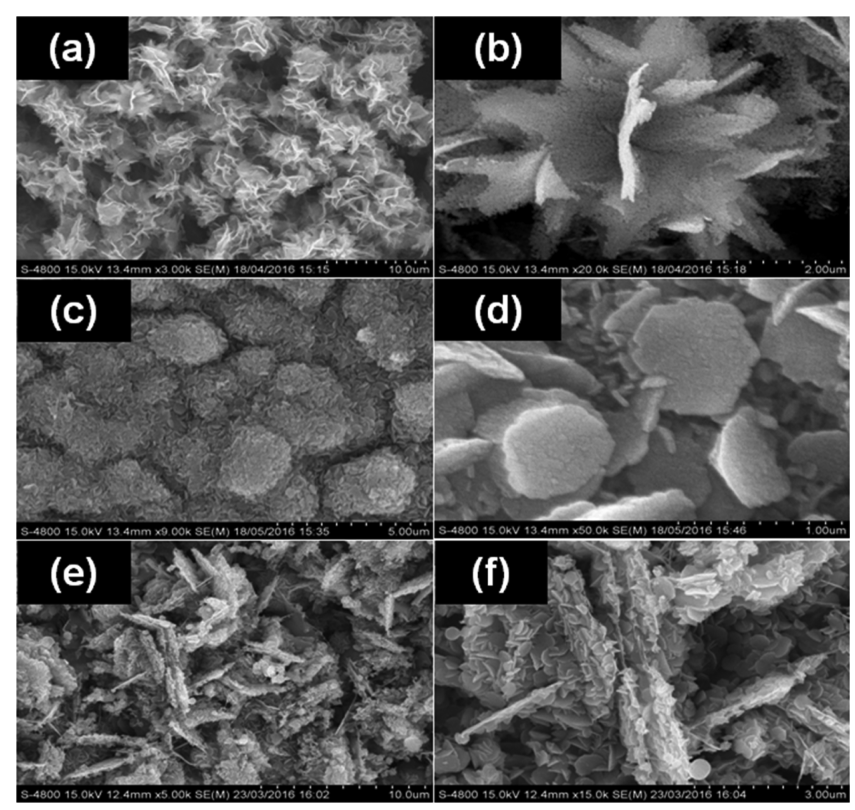

Figure 2. (a,b) SEM image of $2 \mathrm{D}$ porous $\mathrm{ZnO}$ nanosheets, (c,d) $\mathrm{CuSCN}$ nanocoins, and $(\mathrm{e}, \mathrm{f}) \mathrm{ZnO} / \mathrm{CuSCN}$ heterostructure films at low and high magnifications, respectively.

images of the porous $\mathrm{ZnO}$ nanosheets, $\mathrm{CuSCN}$ nanocoins, and $\mathrm{ZnO} / \mathrm{CuSCN}$ nano-heterostructures. Large and uniform coverage of the porous $\mathrm{ZnO}$ nanosheets with an average thickness of $\sim 30 \mathrm{~nm}$ was observed on the entire FTO substrate surface (Figure 2a,b). Similarly, Figure 2c depicts the formation of a large and uniform coverage of well-aligned $\mathrm{CuSCN}$ nanocoins on the entire FTO substrate. The CuSCN nanocoins have an estimated average diameter of $300 \mathrm{~nm}$ and an average thickness of $40 \mathrm{~nm}$, as shown in Figure $2 \mathrm{~d}$. The uniform decoration of $\mathrm{CuSCN}$ nanocoins over the entire surface of the porous $\mathrm{ZnO}$ nanosheets is noticeably observed in Figure 2e. A higher magnification image (Figure 2f) clearly reveals the decoration of interconnected $\mathrm{CuSCN}$ nanocoins over the entire $\mathrm{ZnO}$ nanosheets.

The morphology and crystallinity of the $\mathrm{ZnO} / \mathrm{CuSCN}$ nanoheterostructure were characterized using high-resolution trans- mission electron microscopy (HR-TEM), as shown in Figure 3a (bright field image). The lattice-resolved HRTEM image of

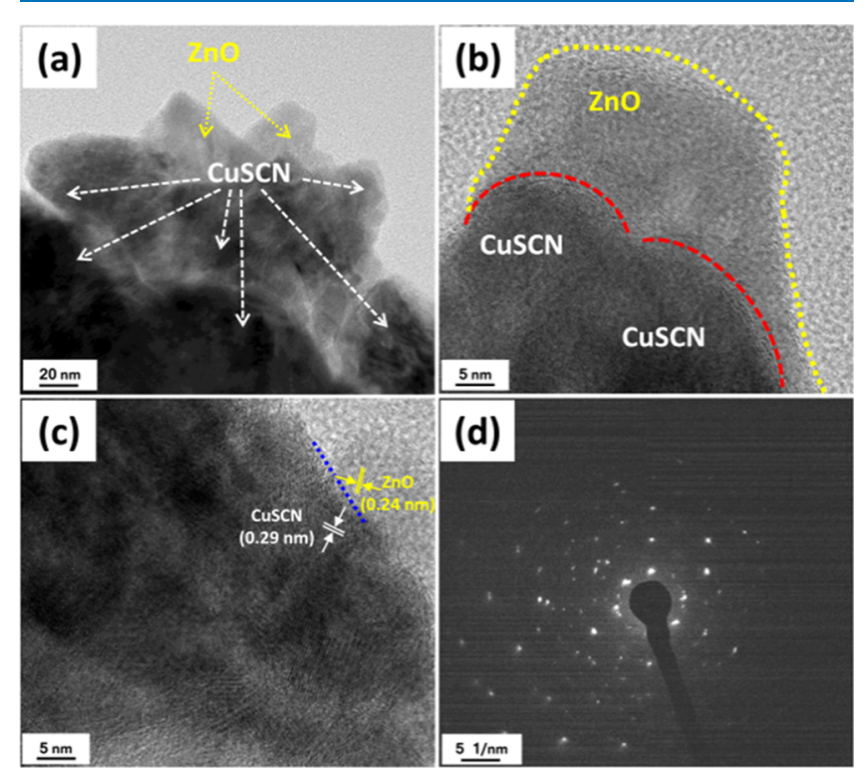

Figure 3. (a) Low magnification bright-field images of the $\mathrm{ZnO} /$ $\mathrm{CuSCN}$ heterostructure, $(\mathrm{b}, \mathrm{c})$ lattice-resolved HRTEM image of the $\mathrm{ZnO} / \mathrm{CuSCN}$ heterostructure and (d) SAED pattern of the $\mathrm{ZnO} /$ $\mathrm{CuSCN}$ heterostructure.

the $\mathrm{ZnO} / \mathrm{CuSCN}$ nano-heterostructure (Figure 3b,c) clearly reveals its crystalline nature. From Figure $3 c$, two distinct fringe patterns with a $d$ spacing of $0.25 \mathrm{~nm}$ corresponding to the (101) lattice plane of $\mathrm{ZnO}$ and $0.29 \mathrm{~nm}$ to the (131) or (112) plane of CuSCN are observed. The interface (denoted by the blue dotted line) between $\mathrm{ZnO}$ and $\mathrm{CuSCN}$ is clearly observed from the HRTEM image (Figure 3c). The selected area electron diffraction (SAED) pattern shown in Figure $3 \mathrm{~d}$ reveals the polycrystalline nature of the $\mathrm{ZnO} / \mathrm{CuSCN}$ nanoheterostructure.

2.3. Optical Absorbance Spectra Analysis. Before performing the comparative $\mathrm{FE}$ measurements of the porous $\mathrm{ZnO}$ nanosheets, $\mathrm{CuSCN}$ nanocoins, and $\mathrm{ZnO} / \mathrm{CuSCN}$ nanoheterostructures, it is also important to investigate the intrinsic optoelectronic properties. Accordingly, UV-visible spectroscopy measurements have been performed to investigate intrinsic optical absorbance characteristics of the $\mathrm{ZnO}$, $\mathrm{CuSCN}$, and the $\mathrm{ZnO} / \mathrm{CuSCN}$ nano-heterostructure films. The variation in optical absorbance for $\mathrm{ZnO}$ films before and after decoration of $\mathrm{CuSCN}$ nanocoins and pristine $\mathrm{CuSCN}$ on FTO as a function of wavelength is as shown in the Supporting Information, Figure S2. The optical absorption edge of porous $\mathrm{ZnO}$ nanosheets is found at $390 \mathrm{~nm}$, whereas for $\mathrm{CuSCN}$ nanocoins, it is $325 \mathrm{~nm}$. After the deposition of CuSCN nanocoins over the porous $\mathrm{ZnO}$ nanosheets, the optical absorption edge shifted to a lower wavelength $(385 \mathrm{~nm}$, i.e., blue shift), which confirms the decoration of the porous $\mathrm{ZnO}$ nanosheets with $\mathrm{CuSCN}$ nanocoins to form the $\mathrm{ZnO} / \mathrm{CuSCN}$ heterostructure.

2.4. FE Studies. Figure $4 \mathrm{a}$ shows the emission current density as a function of the applied electrical field ( $J-E$ curves) for the $\mathrm{ZnO}, \mathrm{CuSCN}$, and $\mathrm{ZnO} / \mathrm{CuSCN}$ nano-heterostructure. In the present case, the turn-on field defined as the field required to draw an emission current density of $10 \mu \mathrm{A} / \mathrm{cm}^{2}$ is found to be $2.2,1.1$, and $0.7 \mathrm{~V} / \mu \mathrm{m}$ for the porous $\mathrm{ZnO}$ 

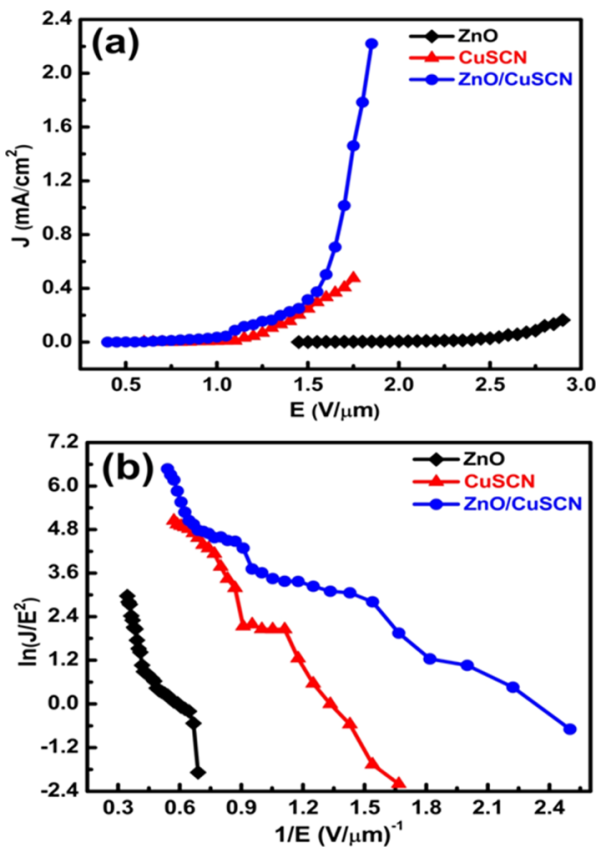

Figure 4. (a) $J-E$ plots of the $\mathrm{ZnO}$ nanosheet, $\mathrm{CuSCN}$ nanocoins, and $\mathrm{ZnO} / \mathrm{CuSCN}$ heterostructure and (b) corresponding $F-N$ plots.

nanosheets, $\mathrm{CuSCN}$ nanocoins, and $\mathrm{ZnO} / \mathrm{CuSCN}$ nanoheterostructures, respectively. A high emission current density of $0.16,0.47$, and $2.2 \mathrm{~mA} / \mathrm{cm}^{2}$ has been achieved from the porous $\mathrm{ZnO}$ nanosheets, $\mathrm{CuSCN}$ nanocoins, and $\mathrm{ZnO} /$ $\mathrm{CuSCN}$ nano-heterostructures upon the application of an electric field of $2.9,1.7$, and $1.8 \mathrm{~V} / \mu \mathrm{m}$, respectively. The observed significant improvement in the FE characteristics (ultralow turn-on field of $0.7 \mathrm{~V} / \mu \mathrm{m}$ for an emission current density of $10 \mu \mathrm{A} / \mathrm{cm}^{2}$ ) for the $\mathrm{ZnO} / \mathrm{CuSCN}$ nanoheterostructure is superior to the porous $\mathrm{ZnO}$ nanosheets, $\mathrm{CuSCN}$ nanocoins, and other nano-heterostructures reported in the literature, as summarized in Table $1 .{ }^{51-56}$ The observed ultralow turn-on field in the case of the $\mathrm{ZnO} / \mathrm{CuSCN}$ nanoheterostructure is attributed to the nanometric feature of $\mathrm{ZnO} / \mathrm{CuSCN}$ : the high density and quasi-aligned nature of $\mathrm{CuSCN}$ nanocoins on porous $\mathrm{ZnO}$ nanosheets (Figure $2 \mathrm{f}$ ). In addition, from Figure $3 b$, it is clear that a crystalline heterojunction is formed between $\mathrm{CuSCN}$ and $\mathrm{ZnO}$ and hence easy percolation of electrons from $\mathrm{ZnO}$ to $\mathrm{CuSCN}$ is more favorable.

The Fowler-Nordheim $(F-N)$ plot, i.e., $\ln \left(J / E^{2}\right)$ versus (1/ $E)$ of the porous $\mathrm{ZnO}$ nanosheets, $\mathrm{CuSCN}$ nanocoins, and $\mathrm{ZnO} / \mathrm{CuSCN}$ nano-heterostructures, is shown in Figure $4 \mathrm{~b}$. The nonlinear nature of the $F-N$ plot is consistent with the semiconducting behavior of the $\mathrm{ZnO}$ nanosheets, CuSCN nanocoins, and $\mathrm{ZnO} / \mathrm{CuSCN}$ nano-heterostructure emitters.
Besides the enhanced performance, the electron emission current stability is an important parameter for device fabrication considerations. Hence, to check the robustness of the $\mathrm{ZnO} / \mathrm{CuSCN}$ nano-heterostructure, we have measured the emission current as a function of time. Shown in Figure 5 is the

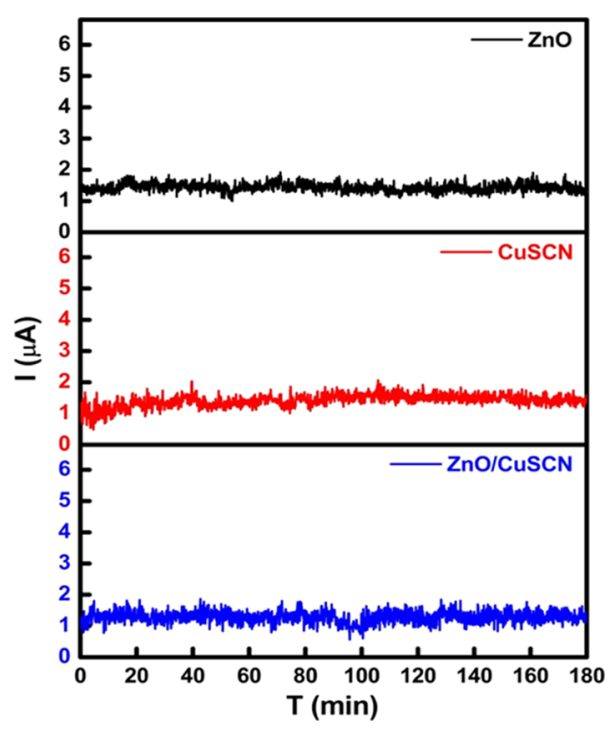

Figure 5. $\mathrm{I}-t$ plots of $\mathrm{ZnO}$ nanosheets, $\mathrm{CuSCN}$ nanocoins, and $\mathrm{ZnO}$ / $\mathrm{CuSCN}$ heterostructures.

emission current versus time $(I-t)$ plot for the $\mathrm{ZnO}$ nanosheets, $\mathrm{CuSCN}$ nanocoins, and $\mathrm{ZnO} / \mathrm{CuSCN}$ nanoheterostructures recorded at the preset value of emission current of $1 \mu \mathrm{A}$ over a period of $3 \mathrm{~h}$. It is evident from the results that the emission current remains quite stable without showing any sign of diminishing over the $3 \mathrm{~h}$ period of continuous testing. The variation in the current density can be attributed to the highly surface-sensitive nature of the FE process; hence, adsorption, desorption, and diffusion of residual species that usually occur in the synthesis could lead to instabilities in the form of spikes.

2.5. DFT Studies. As the FE characteristics depend strongly on the work function $(\Phi)$ of the emitter, we have employed first-principles electronic structure calculations based on DFT to gain insight into the electronic structure and work function of the isolated $\mathrm{CuSCN}$ and $\mathrm{ZnO}$ and their $\mathrm{ZnO} / \mathrm{CuSCN}$ nano-heterostructure. The $\beta$-CuSCN and $\mathrm{ZnO}$ crystals were modeled in the hexagonal crystal system, as shown in Figure 6a,b, respectively. From a full geometry relaxation, the lattice constants of $\beta$-CuSCN were predicted at $a=3.828 \AA$ and $c=10.970 \AA$, which are in good agreement with the experimental values $(a=3.850 \AA$ and $c=10.938 \AA) .{ }^{57}$ The optimized lattice parameters for $\mathrm{ZnO}$ are $a=3.275 \AA$ and

Table 1. Turn-On Field Values of the Nano-Heterostructure Reported in the Literature

\begin{tabular}{|c|c|c|c|}
\hline material & turn-on field $(\mathrm{V} / \mu \mathrm{m})\left(\right.$ for $\left.J=10 \mu \mathrm{A} / \mathrm{cm}^{2}\right)$ & maximum current density $\left(\mu \mathrm{A} / \mathrm{cm}^{2}\right)$ & references \\
\hline $\mathrm{ZnO} / \mathrm{CuSCN}$ nano-heterostructure & 0.7 & $2.2 \mathrm{~mA} / \mathrm{cm}^{2}(1.8 \mathrm{~V} / \mu \mathrm{m})$ & present study \\
\hline $\mathrm{Cu}_{2} \mathrm{O} / \mathrm{ZnO}$ hetero-nanobrush & $\sim 6.5$ & $425(\sim 10.5 \mathrm{~V} / \mu \mathrm{m})$ & 51 \\
\hline $\mathrm{GdB}_{6} / \mathrm{ZnO}$ hetero-architecture & $2.2\left(1 \mu \mathrm{A} / \mathrm{cm}^{2}\right)$ & $4.6\left(\mathrm{~mA} / \mathrm{cm}^{2}\right)(\sim 4.5 \mathrm{~V} / \mu \mathrm{m})$ & 52 \\
\hline $\mathrm{GdB}_{6} / \mathrm{Cu}_{2} \mathrm{O}$ hetero-architecture & $2.3\left(1 \mu \mathrm{A} / \mathrm{cm}^{2}\right)$ & $\sim 900(\sim 5.6 \mathrm{~V} / \mu \mathrm{m})$ & 33 \\
\hline $\mathrm{SnO}_{2} / \mathrm{WO}_{2.72}$ nanowire heterostructures & 0.82 & $\sim 31(\sim 1.04 \mathrm{~V} / \mu \mathrm{m})$ & 54 \\
\hline $\mathrm{CdS}-\mathrm{ZnO}$ heterostructures & 2 & $\sim 1235(\sim 3.36 \mathrm{~V} / \mu \mathrm{m})$ & 55 \\
\hline $\mathrm{HfO}_{2}-\mathrm{ZnO}$ histoarchitecture & $1.84\left(1 \mu \mathrm{A} / \mathrm{cm}^{2}\right)$ & $\sim 885(\sim 3.36 \mathrm{~V} / \mu \mathrm{m})$ & 56 \\
\hline
\end{tabular}



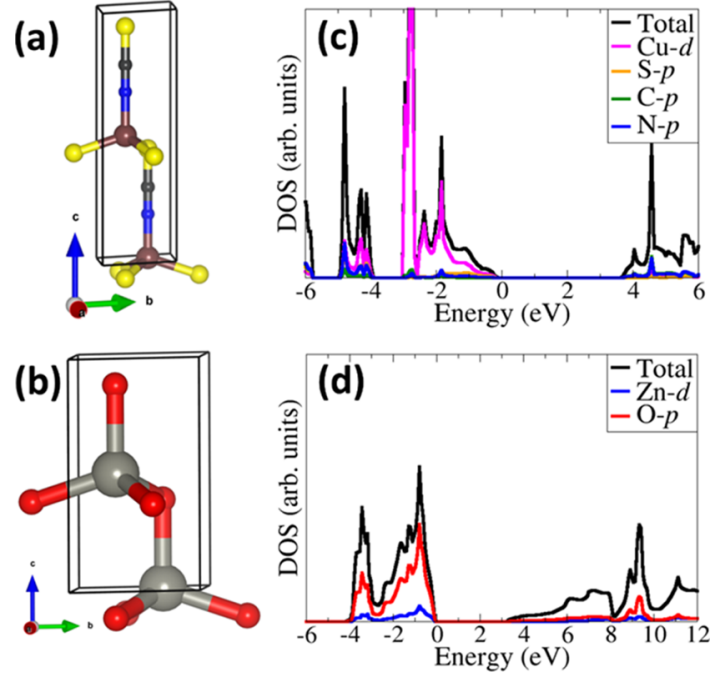

Figure 6. Ball and stick model (a) $\beta$ - $\mathrm{CuSCN}$ and (b) $\mathrm{ZnO}$. The corresponding PDOS is given in $(\mathrm{c}, \mathrm{d})$, respectively. Color code: $\mathrm{Cu}=$ brown; $\mathrm{C}=$ dark gray; $\mathrm{N}=$ blue; $\mathrm{S}=$ yellow; $\mathrm{Zn}=$ light gray; and $\mathrm{O}=$ red.

$c=5.284 \AA$, also in good close agreement with lattice parameters: $a=3.249 \AA$ and $c=5.206 \AA .^{58}$ The electronic band gap of $\mathrm{CuSCN}$ and $\mathrm{ZnO}$ was predicted at 3.68 and 3.24 $\mathrm{eV}$, respectively (Figure $6 \mathrm{c}, \mathrm{d}$ ), using the screened hybrid HSE06 functional ${ }^{59}$ as implemented in the Vienna Ab initio Simulation Package (VASP). ${ }^{60-62}$ The predicted band gaps are in close agreement with previous values of $3.6-3.9 \mathrm{eV}$ for $\mathrm{CuSCN}^{63,64}$ and $3.3 \mathrm{eV}$ for $\mathrm{ZnO}{ }^{58,65}$ The valence band edge of $\mathrm{CuSCN}$ is shown to consist mainly of $\mathrm{Cu}$-d states, whereas for $\mathrm{ZnO}$, it is dominated by $\mathrm{O}-3 \mathrm{p}$ states.

The work function was obtained for the most stable CuSCN $(11 \overline{2} 0)$ and $\mathrm{ZnO}(10 \overline{1} 0)$ surfaces (Figure 7 ), which were (a) CUSCN(112̄o)

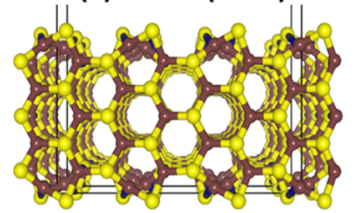

(b) $\mathrm{ZnO}(10 \overline{10})$

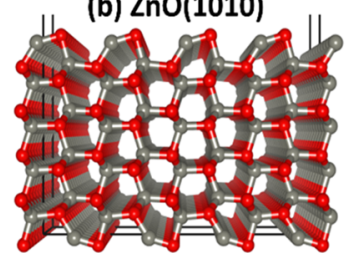

(c) CuSCN/ZnO

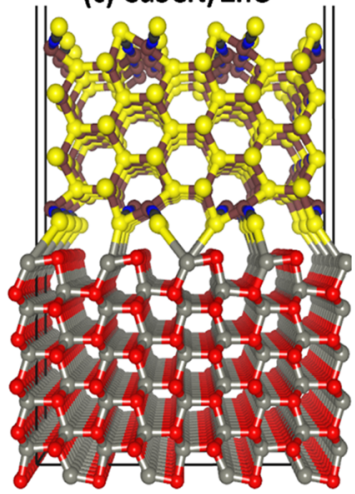

Figure 7. Surface structures of (a) $\mathrm{CuSCN}(11 \overline{2} 0)$ and (b) $\mathrm{ZnO}$ $(10 \overline{10})$ and the equilibrium structure of the (c) $\mathrm{ZnO} / \mathrm{CuSCN}$ heterostructure.

cleaved from the optimized bulk structures. In each simulation cell, a vacuum region of length $15 \AA$ was added perpendicular to the surface to avoid interactions between periodic slabs. The $\mathrm{ZnO} / \mathrm{CuSCN}$ nano-heterostructure was constructed with $(1 \times$ $3)-\mathrm{CuSCN}(11 \overline{2} 0)$ and $(4 \times 4)-\mathrm{ZnO}(10 \overline{1} 0)$ supercells, which ensured that the lattice mismatch at the interface is less than $10 \%$. Shown in Figure 7 is the optimized structure of the $\mathrm{ZnO} /$ $\mathrm{CuSCN}$ nano-heterostructure, with the interface shown to be composed mainly of strong covalent $\mathrm{Zn}-\mathrm{S}$ interactions. The thermodynamic stability of the heterojunctions was evaluated through interfacial adhesion energy, calculated as $E_{\mathrm{ad}}=$ $\left(E_{\mathrm{ZnO} / \mathrm{CuSCN}}-\left(E_{\mathrm{CuSCN}}+E_{\mathrm{ZnO}}\right) / S\right.$, where $E_{\mathrm{ZnO} / \mathrm{CuSCN}}, E_{\mathrm{CuSCN}}$, and $E_{\mathrm{ZnO}}$ are the total energy of the $\mathrm{ZnO} / \mathrm{CuSCN}$ nanoheterostructure with the interface surface area $S$, the individual ground state relaxed total energy of the $\mathrm{CuSCN}$, and $\mathrm{ZnO}$ surfaces, respectively. The adhesion energy of the $\mathrm{ZnO} /$ $\mathrm{CuSCN}$ interfaces was calculated to be $-0.231 \mathrm{eV} \AA^{-2}$, which indicates that the interface structure is thermodynamically stable.

The work function $(\Phi)$ of the isolated $\operatorname{CuSCN}(11 \overline{2} 0)$ and $\mathrm{ZnO}(10 \overline{10})$ surfaces is calculated at 4.91 and $5.24 \mathrm{eV}$, respectively, which compare closely to known experimental measurements of $\mathrm{CuSCN}(\Phi \approx 5 \mathrm{eV})^{66}$ and $\mathrm{ZnO}(\Phi \approx 5.3$ $\mathrm{eV}) .{ }^{67}$ The work function of the $\mathrm{ZnO} / \mathrm{CuSCN}$ nanoheterostructure is predicted at $4.58 \mathrm{eV}$, which is lower than that of the isolated $\mathrm{CuSCN}(11 \overline{2} 0)$ and $\mathrm{ZnO}(10 \overline{1} 0)$ surfaces. The electrostatic potentials for $\mathrm{CuSCN}(11 \overline{2} 0)$ and $\mathrm{ZnO}$ (1010) surfaces and the $\mathrm{ZnO} / \mathrm{CuSCN}$ nano-heterostructure are given in Figure 8. As the work function dictates the

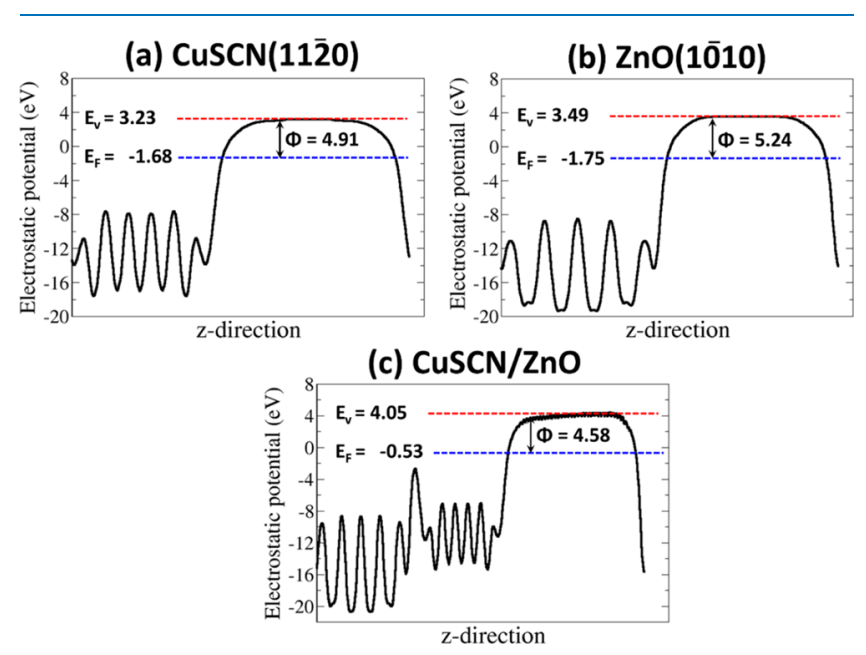

Figure 8. Electrostatic potentials for the (a) CuSCN (11̄̄o) surface, (b) $\mathrm{ZnO}(10 \overline{10})$ surface, and (c) the $\mathrm{ZnO} / \mathrm{CuSCN}$ heterostructure. The red and blue dashed lines represent the vacuum level $\left(E_{\mathrm{vac}}\right)$ and the Fermi level $\left(E_{\mathrm{F}}\right)$, respectively. $\Phi$ is the work function.

electron emission capability of a material, the predicted lower work function of the $\mathrm{ZnO} / \mathrm{CuSCN}$ nano-heterostructure compared to the isolated material counterparts is suggested as the primary origin for the observed enhancement in the FE characteristics in terms of the low turn-on field. Reduction in the work function has been observed in other composite materials compared to the isolated materials. ${ }^{38}$ The higher work function of the $\mathrm{ZnO}(10 \overline{1} 0)$ surface than that of $\mathrm{CuSCN}(1 \overline{1} 0)$ suggests that spontaneous electron transfer will occur from $\mathrm{CuSCN}(11 \overline{2} 0)$ to $\mathrm{ZnO}(10 \overline{1} 0)$ after the two are coupled together. Consistent with this, as shown in Figure 8, the Fermi level $\left(E_{\mathrm{F}}\right)$ of $\operatorname{CuSCN}(11 \overline{2} 0)$ is higher than that of $\mathrm{ZnO}(10 \overline{1} 0)$, again indicating that electrons will transfer from $\mathrm{CuSCN}(1 \overline{1} 0)$ to $\mathrm{ZnO}(10 \overline{10})$ when they are coupled. The transfer will stop and the charge equilibration reached when the $E_{\mathrm{F}}$ position of the $\operatorname{CuSCN}(1120)$ surface becomes the same as that of the $\mathrm{ZnO}(10 \overline{1} 0)$ surface. The calculated energy band alignment between the two materials with respect to a common vacuum level is shown in Figure 9. The conduction 


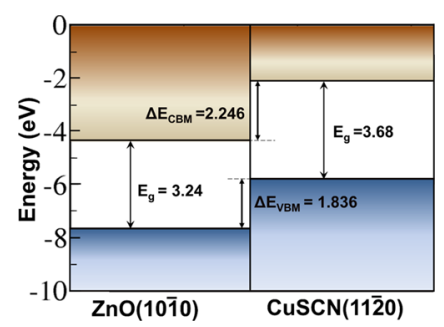

Figure 9. Representative energy band alignment between $\mathrm{ZnO}$ and CuSCN with respect to a common vacuum level.

and valence band offsets between $\mathrm{ZnO}(10 \overline{1} 0)$ and $\mathrm{CuSCN}(1 \overline{1} 0)$ are predicted at 2.25 and $1.84 \mathrm{eV}$, respectively. The ionization potential (IP), which indicates the position where the valence band edge is observed, is calculated at 7.68 $\mathrm{eV}$ for $\mathrm{ZnO}(10 \overline{10} 0)$ and $5.84 \mathrm{eV}$ for $\operatorname{CuSCN}(11 \overline{2} 0)$. The lower conduction and valence band edges of $\mathrm{ZnO}(10 \overline{1} 0)$ than $\operatorname{CuSCN}(1 \overline{1} \overline{2} 0)$ with a type-II band alignments suggest that conduction electrons will migrate to the $\mathrm{ZnO}(1010)$ and valence holes to $\mathrm{CuSCN}(11 \overline{2} 0)$.

\section{CONCLUSIONS}

In summary, we report a cost-effective and simple solution chemical routes of chemical bath deposition (CBD) and successive ionic layer adsorption and reaction (SILAR) methods to prepare $\mathrm{ZnO}$ nanosheets, CuSCN nanocoins, and $\mathrm{ZnO} / \mathrm{CuSCN}$ nano-heterostructures at low temperatures. The formation of the $\mathrm{ZnO} / \mathrm{CuSCN}$ nano-heterostructure is demonstrated to result in significant improvement in FE characteristics. The turn-on field required to draw a current density of $10 \mu \mathrm{A} / \mathrm{cm}^{2}$ is found to be $2.2,1.1$, and $0.7 \mathrm{~V} / \mu \mathrm{m}$ for the $\mathrm{ZnO}, \mathrm{CuSCN}$, and $\mathrm{ZnO} / \mathrm{CuSCN}$ nano-heterostructure, respectively. The superior $\mathrm{FE}$ characteristics of the $\mathrm{ZnO} /$ $\mathrm{CuSCN}$ nano-heterostructure compared to the isolated $\mathrm{ZnO}$ and $\mathrm{CuSCN}$ materials can be ascribed to the lower work function of the $\mathrm{ZnO} / \mathrm{CuSCN}$ nano-heterostructure compared to the individual $\mathrm{ZnO}$ and $\mathrm{CuSCN}$ materials. Our analyses and results provide an efficient strategy for improving the $\mathrm{FE}$ characteristics in related composite nanostructures via morphological and electronic modifications.

\section{EXPERIMENTAL DETAILS}

4.1. Synthesis of Porous ZnO Nanosheets. All chemicals were purchased from Sigma-Aldrich and Merck, India, and were used as received without further purification. Prior to the deposition, the FTO-coated glass substrate with a sheet resistance of about $\sim 10 \Omega / \mathrm{cm}^{2}$ was ultrasonically cleaned using soap solution followed by rinsing with acetone for $15 \mathrm{~min}$ and then finally rinsing with double distilled water (hereafter DDW). The synthesis of porous $\mathrm{ZnO}$ nanosheets was performed using a soft chemical route on the precleaned FTO substrate. The synthesis process includes (i) modification of the FTO substrate with a thin and compact layer of uniformly coated $\mathrm{ZnO}$ nanoparticles using the modified chemical bath deposition (M-CBD) technique, followed by (ii) growth of porous $\mathrm{ZnO}$ nanosheets in aqueous solution using the CBD method. ${ }^{6}$ The film synthesis was performed at low temperature $\left(<100{ }^{\circ} \mathrm{C}\right)$ followed by annealing at $200{ }^{\circ} \mathrm{C}$ for $1 \mathrm{~h}$ to obtain the pure $\mathrm{ZnO}$ phase. The complete reaction mechanism and preparation parameters were similar to those reported in the work of Baviskar et al. ${ }^{69}$
Concisely, for the deposition of a dense/compact $\mathrm{ZnO}$ layer, $0.05 \mathrm{M}$ zinc acetate dihydrate solution was prepared in DDW with addition of $25 \% \mathrm{NH}_{3}$ till the $\mathrm{pH}$ becomes $\sim 11$. This resultant solution was used as a source of cations which was kept at room temperature and the DDW maintained at $90{ }^{\circ} \mathrm{C}$ is used as the anion source. The modified CBD technique was used for the deposition of the dense/compact $\mathrm{ZnO}$ layer over the FTO substrate. The dipping time in a cationic and anionic precursor was 5 and $10 \mathrm{~s}$, respectively. A similar process was repeated for 20 immersion cycles to get a uniform and compact $\mathrm{ZnO}$ layer. Finally, the deposited films were washed with DDW, dried in air followed by annealing at $200{ }^{\circ} \mathrm{C}$ for $1 \mathrm{~h}$, and used for further deposition of porous $\mathrm{ZnO}$.

Porous $\mathrm{ZnO}$ nanosheets were chemically deposited using a mixture solution of zinc acetate dihydrate $(0.2 \mathrm{M})$ and hexamine (hereafter HMTA, $0.02 \mathrm{M}$ ) in DDW. In order to maintain the $\mathrm{pH}$ at $\sim 11,25 \% \mathrm{NH}_{3}$ solution as a complexing agent was added with constant stirring. The premodified FTO substrate (coated with dense $\mathrm{ZnO}$ ) was introduced into the above mentioned solution bath and maintained at room temperature for $20 \mathrm{~h}$. The as-deposited film was then annealed at $200{ }^{\circ} \mathrm{C}$ for $1 \mathrm{~h}$ to remove the hydroxides and improve the crystallinity of the nanosheets.

4.2. Decoration of Porous ZnO Nanosheets with CuSCN Nanocoins by SILAR. The decoration of CuSCN nanocoins on the porous $\mathrm{ZnO}$ nanosheets was carried out using the SILAR technique at room temperature. ${ }^{70}$ The anionic precursor was prepared by adding $100 \mathrm{mM}$ copper sulphate and $100 \mathrm{mM}$ sodium thiosulphate in DDW. The sodium thiosulphate acts as a reducing and complexing agent. Potassium thiocyanate $(70 \mathrm{mM})$ in DDW was used as a cationic precursor. The immersion time was kept at $15 \mathrm{~s}$ in both anionic and cationic precursors. The rinsing was performed for $10 \mathrm{~s}$ in ion-exchanged DDW. The immersion cycles were repeated for 20 cycles in order to optimize the uniform coverage of $\mathrm{CuSCN}$ nanocoins over the porous surface of $\mathrm{ZnO}$ nanosheet films followed by final rinsing with DDW and drying in air at room temperature.

4.3. Reaction Mechanism. It is well-known that the structure and morphology of crystals depend on the intrinsic property and external conditions. It is hard to alter the intrinsic properties of the material but easy to tailor the external conditions. The formation of $\mathrm{ZnO}$ sheet-like morphology can be justified with $\mathrm{OH}^{-}$ion concentration ${ }^{71}$ supplied from aq $\mathrm{NH}_{3}$ and reduction of HMTA to $\mathrm{HCOH}$ (formaldehyde) and $\mathrm{NH}_{3}$ (ammonia) in the solution bath (eqs 1 and 2). ${ }^{72}$ In the present case, the excess $\mathrm{OH}^{-}$ions and abundant $\mathrm{Zn}\left[\left(\mathrm{NH}_{3}\right)_{4}\right]^{2+}$ anions (eqs 3-5) can stabilize the surface charge and the structure of $\mathrm{Zn}(001)$ surfaces to some extent. ${ }^{73}$ Growth along (100) and (101) planes was dominant over the (002) direction because of excess $\mathrm{OH}^{-}$ions and high concentration of $\mathrm{Zn}^{2+}$ ions in the reaction bath, which resulted in the formation of $\mathrm{ZnO}$ nanosheets after annealing (eqs 6 and 7) and the same is also supported by XRD results.

$$
\begin{aligned}
& \left(\mathrm{CH}_{2}\right)_{6} \mathrm{~N} 4+6 \mathrm{H}_{2} \mathrm{O} \rightarrow 4 \mathrm{NH}_{3}+6 \mathrm{HCHO} \\
& 2 \mathrm{NH}_{3}+2 \mathrm{H}_{2} \mathrm{O} \rightarrow 2 \mathrm{NH}_{4}^{+}+2 \mathrm{OH}^{-} \\
& \mathrm{Zn}\left(\mathrm{C}_{2} \mathrm{H}_{3} \mathrm{O}_{2}\right)_{2} \rightarrow \mathrm{Zn}^{2+}+2 \mathrm{CH}_{3} \mathrm{COO}^{-} \\
& \mathrm{Zn}^{2+}+4 \mathrm{NH}_{3} \rightarrow \mathrm{Zn}\left[\left(\mathrm{NH}_{3}\right)_{4}\right]^{2+}
\end{aligned}
$$




$$
\begin{aligned}
& \mathrm{CH}_{3} \mathrm{COO}^{-}+\mathrm{H}_{2} \mathrm{O} \rightarrow \mathrm{CH}_{3} \mathrm{COOH}+\mathrm{OH}^{-} \\
& \mathrm{Zn}\left[\left(\mathrm{NH}_{3}\right)_{4}\right]^{2+}+2 \mathrm{OH}^{-} \rightarrow \mathrm{Zn}(\mathrm{OH})_{2}+\mathrm{H}_{2} \mathrm{O}+\mathrm{NH}_{3} \uparrow \\
& \mathrm{Zn}(\mathrm{OH})_{2} \stackrel{\Delta}{\rightarrow} \mathrm{ZnO}+\mathrm{H}_{2} \mathrm{O}
\end{aligned}
$$

In the SILAR technique, the cationic and anionic solutions alternately react via the precursor decomposition process on the surface of the immersed substrate to yield heterogeneous nucleation and growth of the desired film. ${ }^{74}$ Initially, copper(II) sulfate and sodium thiosulfate dissolve in DDW, leading to the release of cupric and thiosulfate ions, respectively, in the solution. These thiosulfate ions are useful in reducing cupric ions $\left(\mathrm{Cu}^{2+}\right)$ to cuprous ions $\left(\mathrm{Cu}^{+}\right)$. Later, a redox reaction between the cuprous and thiosulfate ions results in the formation of the thiosulphatocuprate(I) complex (eq 8).

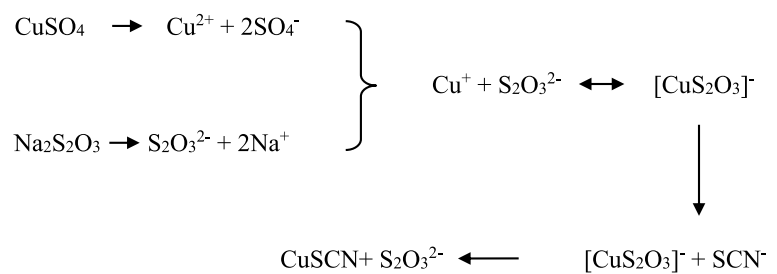

The thiosulphatocuprate(I) complex is then reacted with thiocyanate ions to form solid CuSCN (eq 9). The powdery material or loosely bounded ions were removed by rinsing the substrate in DDW.

4.4. Characterizations and Measurements. Structural properties of the films were measured using an X-ray diffractometer (Bruker D8 ADVANCE) with $\mathrm{Cu} \mathrm{K} \alpha$ radiations $(\lambda=1.5406 \AA)$ in the $2 \theta$ range from 10 to $80^{\circ}$. The optical absorption spectra were measured by UV-vis spectrophotometer (Shimadzu, model no. UV 2600) in the wavelength range between 300 and $800 \mathrm{~nm}$. Raman spectra of the films were recorded in the spectral range of $100-3200 \mathrm{~cm}^{-1}$ using a Jobin-Yvon T64000 Raman scattering system with an Olympus microscope equipped with a 50x magnification lens in a backscattered configuration. A Nd:YAG laser was used as an exciton source operated at $532 \mathrm{~nm}$ wavelength and an output power of $\sim 10 \mathrm{~mW}$ was focused on the sample using a fiber optic probe head. The surface morphology of the nanostructure films was observed using a field emission scanning electron microscope (Hitachi S-4800) and using a transmission electron microscope (Tecnai G2 20 Twin, FEI). EDS attached with an FESEM unit was used to determine the elemental compositions of chemically prepared $\mathrm{ZnO}, \mathrm{CuSCN}$, and $\mathrm{ZnO} /$ $\mathrm{CuSCN}$ nano-heterostructure films. The FE measurements such as current density-applied field $(J-E)$ and current-time $(I-t)$ were carried out in a "close-proximity" (planar diode) configuration using an ultrahigh vacuum (UHV) field emission microscopy (FEM) system (Excel Instruments model: I-100). The schematic presentation of the FE experimental setup is shown in Scheme 1. The $\mathrm{ZnO}, \mathrm{CuSCN}$, and $\mathrm{ZnO} / \mathrm{CuSCN}$ nano-heterostructure grown onto the FTO-coated glass substrate served as the cathode and FTO served as the anode. Provision for the back contact was performed using a conducting carbon tape with the anode and cathode separation distance kept at $1 \mathrm{~mm}$. The area $(A)$ of all emitters was 0.25 $\mathrm{cm}^{2}$ and the current density $J$ is defined as $J=I / A$, where $I$ is the emission current. The UHV FEM system was heated for 12 $\mathrm{h}$ at $150^{\circ} \mathrm{C}$ and a pressure of $1 \times 10^{-8} \mathrm{mbar}$ was achieved. The
Scheme 1. Schematic Presentation of the Field Emission Experimental Setup

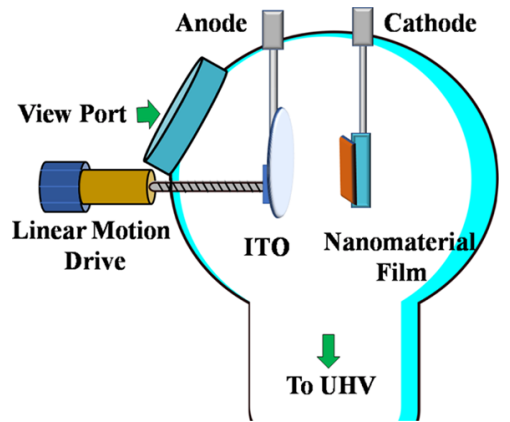

current calibration was performed by measuring the voltage across a resistor, and for dc high voltage application, Glassman (USA) power supply was used.

The first-principles DFT calculations were performed using the Vienna $\mathrm{Ab}$ initio Simulation Package (VASP), ${ }^{60-62}$ a periodic plane wave DFT code which includes the interactions between the core and valence electrons using the project augmented wave (PAW) method. ${ }^{75}$ An energy cutoff of $600 \mathrm{eV}$ and a Monkhorst-Pack ${ }^{76} k$-point mesh of $7 \times 5 \times 3$ and $7 \times 7$ $\times 5$ were used to sample the Brillouin zone of the bulk CuSCN and $\mathrm{ZnO}$, respectively. Geometry optimizations were performed using the conjugate-gradient algorithm until the residual Hellmann-Feynman forces on all relaxed atoms reached $10^{-3} \mathrm{eV} \AA^{-1}$. The electronic exchange-correlation potential was calculated using the Perdew-Burke-Ernzerhof generalized gradient approximation functional. ${ }^{77}$ To accurately reproduce the experimentally known band gaps and density of states features of $\mathrm{CuSCN}$ and $\mathrm{ZnO}$, the screened hybrid functional HSE06 ${ }^{59}$ was used with the exchange values of 5 and $25 \%$, respectively. The projected density of states (PDOS) was calculated using the tetrahedron method with Bloch correction. $^{78}$

The surfaces of $\mathrm{CuSCN}$ and $\mathrm{ZnO}$ were created from the optimized bulk materials using the METADISE code, ${ }^{79}$ which ensures the creation of surfaces with zero dipole moment perpendicular to the surface plane. ${ }^{80} \mathrm{CuSCN}(11 \overline{2} 0)$ and $\mathrm{ZnO}$ (1010) were considered for the nano-heterostructure $\mathrm{ZnO} /$ $\mathrm{CuSCN}$ formation because these do not contain any dangling bonds and resulted in low energy and nonpolar terminations. In order to align the energies to the vacuum level, a slab-gap model was constructed, and the corresponding electrostatic potential was averaged along the $c$-direction, using the Macro Density package. ${ }^{81-83}$ The work function $(\Phi)$ was calculated as $\Phi=V_{\text {vacuum }}-E_{\mathrm{F}}$, where $V_{\text {vacuum }}$ and $E_{\mathrm{F}}$ are the vacuum and Fermi level, respectively. Dipole correction perpendicular to all surfaces was accounted, which ensured that there is no net dipole perpendicular to the surfaces that may affect the potential in the vacuum level. The IPs were calculated when the slab vacuum level is aligned to the bulk eigenvalues, through the core level eigenvalues in the center of the slab, using the 1 s orbital of $\mathrm{O}(\mathrm{ZnO})$ and $\mathrm{S}(\mathrm{CuSCN})$ as the reference point.

\section{ASSOCIATED CONTENT}

\section{SI Supporting Information}

The Supporting Information is available free of charge at https://pubs.acs.org/doi/10.1021/acsomega.0c00006. 
Dispersive X-ray spectroscopy composition analysis spectra, cross-sectional mapping, and optical absorption spectra (PDF)

\section{AUTHOR INFORMATION}

\section{Corresponding Author}

Nelson Y. Dzade - School of Chemistry, Cardiff University, Cardiff CF10 3AT, U.K.; @ orcid.org/0000-0001-77339473; Email: DzadeNY@cardiff.ac.uk

\section{Authors \\ Prashant K. Baviskar - Department of Physics, SN Arts, DJ Malpani Commerce \& BN Sarda Science College, Sangamner 422605, India; (i) orcid.org/0000-0003-2278-9412 \\ Sachin R. Rondiya - School of Chemistry, Cardiff University, Cardiff CF10 3AT, U.K. \\ Girish P. Patil - SVKM's Institute of Technology, Dhule 424001, India \\ Babasaheb R. Sankapal - Nano Materials and Device Laboratory, Department of Physics, Visvesvaraya National Institute of Technology, Nagpur 440010, India; 이이.org/ 0000-0002-7464-9633 \\ Habib M. Pathan - Advanced Physics Laboratory, Department of Physics, Savitribai Phule Pune University, Pune 411007, India \\ Padmakar G. Chavan - Department of Physics, School of Physical Sciences, KBC North Maharashtra University, Jalgaon 425001, India}

Complete contact information is available at:

https://pubs.acs.org/10.1021/acsomega.0c00006

\section{Author Contributions}

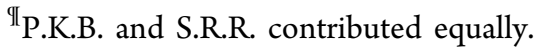

Notes

The authors declare no competing financial interest.

\section{ACKNOWLEDGMENTS}

P.K.B. is thankful to the Department of Science and Technology, Govt. of India, New Delhi, for financial assistance under the DST-FIST scheme (SR/FST/College-258/2015) and the DBT star college scheme. G.P.P. and P.G.C. sincerely thank the DST-SERB, Government of India (ref. no. SB/ EMEQ-208/2013), for financial support. S.R.R. and N.Y.D. acknowledge the UK Engineering and Physical Sciences Research Council (EPSRC) for funding (grant no. EP/ S001395/1). This work has also used the computational facilities of the Advanced Research Computing at Cardiff (ARCCA) Division, Cardiff University, and HPC Wales. This work also made use of the facilities of ARCHER (http://www. archer.ac.uk), the UK's national supercomputing service via the membership of the UK's HEC Materials Chemistry Consortium, which is funded by EPSRC (EP/L000202). Information on the data that underpins the results presented here, including how to access them, can be found in the Cardiff University data catalogue at http://doi.org/10.17035/d.2020. 0102985077 .

\section{REFERENCES}

(1) Berger, M. Nanotechnology: The Future is Tiny; Royal Society of Chemistry, 2016; pp 85-114.
(2) Li, Y.; Koshizaki, N.; Cai, W. Periodic One-Dimensional Nanostructured Arrays Based on Colloidal Templates, Applications, and Devices. Coord. Chem. Rev. 2011, 255, 357-373.

(3) Weng, W. Y.; Chang, S. J.; Hsu, C. L.; Hsueh, T. J. A ZnONanowire Phototransistor Prepared on Glass Substrates. ACS Appl. Mater. Interfaces 2011, 3, 162-166.

(4) Lupan, O.; Pauporté, T.; Viana, B.; Tiginyanu, I. M.; Ursaki, V. V.; Cortès, R. Epitaxial Electrodeposition of $\mathrm{ZnO}$ Nanowire Arrays on p-GaN for Efficient UV-Light-Emitting Diode Fabrication. ACS Appl. Mater. Interfaces 2010, 2, 2083-2090.

(5) Li, Y.; Fang, X.; Koshizaki, N.; Sasaki, T.; Li, L.; Gao, S.; Shimizu, Y.; Bando, Y.; Golberg, D. Periodic $\mathrm{TiO}_{2}$ Nanorod Arrays with Hexagonal Nonclose-Packed Arrangements: Excellent Field Emitters by Parameter Optimization. Adv. Funct. Mater. 2009, 19, 2467-2473.

(6) Guan, J.; Zhang, J.; Yu, T.; Xue, G.; Yu, X.; Tang, Z.; Wei, Y.; Yang, J.; Li, Z.; Zou, Z. Interfacial Modification of Photoelectrode in ZnO-based Dye-Sensitized Solar Cells and its Efficiency Improvement Mechanism. RSC Adv. 2012, 2, 7708-7713.

(7) Lee, C. J.; Lee, T. J.; Lyu, S. C.; Zhang, Y.; Ruh, H.; Lee, H. J. Field Emission from Well-Aligned Zinc Oxide Nanowires Grown at Low Temperature. Appl. Phys. Lett. 2002, 81, 3648.

(8) Xu, C. X.; Sun, X. W. Field Emission from Zinc Oxide Nanopins. Appl. Phys. Lett. 2003, 83, 3806.

(9) Li, Y. B.; Bando, Y.; Golberg, D. ZnO Nanoneedles with Tip Surface Perturbations: Excellent Field Emitters. Appl. Phys. Lett. 2004, 84, 3603.

(10) Zhao, Q.; Zhang, H. Z.; Zhu, Y. W.; Feng, S. Q.; Sun, X. C.; Xu, J.; Yu, D. P. Morphological Effects on the Field Emission of $\mathrm{ZnO}$ Nanorod Arrays. Appl. Phys. Lett. 2005, 86, 203115.

(11) Lai, L.-T.; Chang, S.-J.; Yang, C.-C.; Young, S.-J. UV-enhanced 2-d nanostructured $\mathrm{ZnO}$ field emitter with adsorbed Pt nanoparticles. IEEE Electron Device Lett. 2018, 39, 1932-1935.

(12) Premkumar, T.; Zhou, Y. S.; Lu, Y. F.; Baskar, K. Optical and Field-Emission Properties of $\mathrm{ZnO}$ Nanostructures Deposited Using High-Pressure Pulsed Laser Deposition. ACS Appl. Mater. Interfaces 2010, 2, 2863-2869.

(13) Bekermann, D.; Gasparotto, A.; Barreca, D.; Bovo, L.; Devi, A.; Fischer, R. A.; Lebedev, O. I.; Maccato, C.; Tondello, E.; Van Tendeloo, G. Highly Oriented $\mathrm{ZnO}$ Nanorod Arrays by a Novel Plasma Chemical Vapor Deposition Process. Cryst. Growth Des. 2010, 10, 2011-2018

(14) Barreca, D.; Bekermann, D.; Devi, A.; Fischer, R. A.; Gasparotto, A.; Maccato, C.; Tondello, E.; Rossi, M.; Orlanducci, S.; Terranova, M. L. Novel Insight into the Alignment and Structural Ordering of Supported ZnO Nanorods. Chem. Phys. Lett. 2010, 500, 287-290.

(15) Ong, C. B.; Ng, L. Y.; Mohammad, A. W. A Review of ZnO Nanoparticles as Solar Photocatalysts: Synthesis, Mechanisms and Applications. Renewable Sustainable Energy Rev. 2018, 81, 536-551.

(16) Simon, Q.; Barreca, D.; Gasparotto, A.; Maccato, C.; Montini, T.; Gombac, V.; Fornasiero, P.; Lebedev, O. I.; Turner, S.; Van Tendeloo, G. Vertically Oriented $\mathrm{CuO} / \mathrm{ZnO}$ Nanorod Arrays: from Plasma-Assisted Synthesis to Photocatalytic $\mathrm{H}_{2}$ Production. J. Mater. Chem. 2012, 22, 11739-11747.

(17) Postica, V.; Vahl, A.; Santos-Carballal, D.; Dankwort, T.; Kienle, L.; Hoppe, M.; Cadi-Essadek, A.; de Leeuw, N. H.; Terasa, M.-I.; Adelung, R.; Faupel, F.; Lupan, O. Tuning ZnO Sensors Reactivity toward Volatile Organic Compounds via Ag Doping and Nanoparticle Functionalization. ACS Appl. Mater. Interfaces 2019, 11, 31452-31466.

(18) Kim, J.-W.; Porte, Y.; Ko, K. Y.; Kim, H.; Myoung, J.-M. Micropatternable Double-Faced ZnO Nanoflowers for Flexible Gas Sensor. ACS Appl. Mater. Interfaces 2017, 9, 32876-32886.

(19) Young, S.-J.; Lai, L.-T. Electron Field Emission Enhancement Based on Pt-Adsorbed $\mathrm{ZnO}$ Nanorods With UV Irradiation. IEEE Trans. Nanotechnol. 2018, 17, 1063-1068.

(20) Young, S.-J.; Liu, Y.-H.; Chien, J.-T. Improving Field Electron Emission Properties of $\mathrm{ZnO}$ Nanosheets with Ag Nanoparticles 
Adsorbed by Photochemical Method. ACS Omega 2018, 3, 81358140 .

(21) Lee, J. Y.; Choi, Y. S.; Kim, J. H.; Park, M. O.; Im, S. Optimizing $\mathrm{n}-\mathrm{ZnO} / \mathrm{p}-\mathrm{Si}$ Heterojunctions for Photodiode Applications. Thin Solid Films 2002, 403-404, 553-557.

(22) Chu, S.; Lim, J. H.; Mandalapu, L. J.; Yang, Z.; Li, L.; Liu, J. L. $\mathrm{Sb}$-doped $\mathrm{p}-\mathrm{ZnO} / \mathrm{Ga}$-doped $\mathrm{n}-\mathrm{ZnO}$ Homojunction Ultraviolet Light Emitting Diodes. Appl. Phys. Lett. 2008, 92, 152103.

(23) Huang, J.; Yin, Z.; Zheng, Q. Applications of $\mathrm{ZnO}$ in Organic and Hybrid Solar Cells. Energy Environ. Sci. 2011, 4, 3861-3877.

(24) Wei, L.; Yu, C.; Zhang, Q.; Liu, H.; Wang, Y. $\mathrm{TiO}_{2}$-based Heterojunction Photocatalysts for Photocatalytic Reduction of $\mathrm{CO}_{2}$ into Solar Fuels. J. Mater. Chem. A 2018, 6, 2241-22436.

(25) Mishra, M.; Gundimeda, A.; Garg, T.; Dash, A.; Das, S.; Vandana, V.; Gupta, G. ZnO/GaN Heterojunction Based SelfPowered Photodetectors: Influence of Interfacial States on UV Sensing. Appl. Surf. Sci. 2019, 478, 1081-1089.

(26) Baviskar, P. K.; Zhang, J. B.; Gupta, V.; Chand, S.; Sankapal, B. R. Nanobeads of Zinc Oxide with Rhodamine B dye as a Sensitizer for Dye Sensitized Solar Cell Application. J. Alloys Compd. 2012, 510, 33-37.

(27) Huang, M. H.; Wu, Y.; Feick, H.; Tran, N.; Weber, E.; Yang, P. Catalytic Growth of Zinc Oxide Nanowires by Vapor Transport. Adv. Mater. 2001, 13, 113.

(28) Pan, Z. W.; Dai, Z. R.; Wang, Z. L. Nanobelts of Semiconducting Oxides. Science 2001, 291, 1947-1949.

(29) Young, S.-J.; Wang, T.-H. ZnO Nanorods Adsorbed with Photochemical Ag Nanoparticles for IOT and Field Electron Emission Application. J. Electrochem. Soc. 2018, 165, B3043-B3045.

(30) Wu, J.-J.; Liu, S.-C.; Wu, C.-T.; Chen, K.-H.; Chen, L.-C. Heterostructures of $\mathrm{ZnO}-\mathrm{Zn}$ Coaxial Nanocables and $\mathrm{ZnO}$ Nanotubes. Appl. Phys. Lett. 2002, 81, 1312.

(31) Hu, J. Q.; Bando, Y.; Zhan, J. H.; Li, Y. B.; Sekiguchi, T. Twodimensional micrometer-sized single-crystalline $\mathrm{ZnO}$ thin nanosheets. Appl. Phys. Lett. 2003, 83, 4414.

(32) Cole, J. J.; Wang, X.; Knuesel, R. J.; Jacobs, H. O. Integration of ZnO Microcrystals with Tailored Dimensions Forming Light Emitting Diodes and UV Photovoltaic Cells. Nano Lett. 2008, 8, 1477-1481.

(33) Sun, H.; Zhang, Q.-F.; Wu, J.-L. Electroluminescence from $\mathrm{ZnO}$ nanorods with an $\mathrm{n}-\mathrm{ZnO} / \mathrm{p}-\mathrm{Si}$ Heterojunction Structure. Nanotechnology 2006, 17, 2271.

(34) Ghosh, R.; Basak, D. Electrical and Ultraviolet Photoresponse Properties of Quasialigned $\mathrm{ZnO}$ Nanowires/p-Si Heterojunction. Appl. Phys. Lett. 2007, 90, 243106.

(35) Mohanta, K.; Batabyal, S. K.; Pal, A. J. Organization of Organic Molecules with Inorganic Nanoparticles: Hybrid Nanodiodes. Adv. Funct. Mater. 2008, 18, 687-693.

(36) Tena-Zaera, R.; Ryan, M. A.; Katty, A.; Hodes, G.; Bastide, S.; Lévy-Clément, C. Fabrication and Characterization of $\mathrm{ZnO}$ Nanowires/CdSe/CuSCN Eta-Solar Cell. C. R. Chim. 2006, 9, 717-729.

(37) Young, S.-J.; Lai, L.-T. UV Illumination and Au Nanoparticles Enhanced $\mathrm{ZnO}$ Nanorods Field Electron Emission Device. IEEE Trans. Electron Devices 2020, 67, 304-308.

(38) Chang, Y.-M.; Lin, M.-L.; Lai, T.-Y.; Lee, H.-Y.; Lin, C.-M.; Wu, Y.-C. S.; Juang, J.-Y. Field Emission Properties of Gold Nanoparticle-Decorated ZnO Nanopillars. ACS Appl. Mater. Interfaces 2012, 4, 6676

(39) Rout, C. S.; Joshi, P. D.; Kashid, R. V.; Joag, D. S.; More, M. A.; Simbeck, A. J.; Washington, M.; Nayak, S. K.; Late, D. J. Superior Field Emission Properties of Layered $\mathrm{WS}_{2}$-RGO Nanocomposites. Sci. Rep. 2013, 3, 3282.

(40) Ni, Y.; Jin, Z.; Yu, K.; Fu, Y.; Liu, T.; Wang, T. Electrochemical deposition characteristics of $\mathrm{p}-\mathrm{CuSCN}$ on $\mathrm{n}-\mathrm{ZnO}$ rod arrays films. Electrochim. Acta 2008, 53, 6048-6054.

(41) O’Regan, B.; Schwartz, T. D. Efficient Photo-Hole Injection from Adsorbed Cyanine Dyes into Electrodeposited Copper(I) Thiocyanate Thin Films. Chem. Mater. 1995, 7, 1349-1354.
(42) Li, B.; Wang, L.; Kang, B.; Wang, P.; Qiu, Y. Review of Recent Progress in Solid-State Dye-Sensitized Solar Cells. Sol. Energy Mater. Sol. Cells 2006, 90, 549-573.

(43) Laurent, K.; Brouri, T.; Capo-Chichi, M.; Yu, D. P.; LeprinceWang, Y. Study on the Structural and Physical Properties of $\mathrm{ZnO}$ Nanowire Arrays Grown via Electrochemical and Hydrothermal Depositions. J. Appl. Phys. 2011, 110, 094310.

(44) Tena-Zaera, R.; Katty, A.; Bastide, S.; Lévy-Clément, C.; O’Regan, B.; Muñoz-Sanjosé, V. ZnO/CdTe/CuSCN, a Promising Heterostructure to Act as Inorganic eta-Solar Cell. Thin Solid Films 2005, 483, 372-377.

(45) Edri, E.; Cohen, H.; Hodes, G. Band Alignment in Partial and Complete $\mathrm{ZnO} / \mathrm{ZnS} / \mathrm{CdS} / \mathrm{CuSCN}$ Extremely Thin Absorber Cells: An X-ray Photoelectron Spectroscopy Study. ACS Appl. Mater. Interfaces 2013, 5, 5156-5164.

(46) Chen, S. J.; Liu, Y. C.; Shao, C. L.; Mu, R.; Lu, Y. M.; Zhang, J. Y.; Shen, D. Z.; Fan, X. W. Structural and Optical Propertiesof Uniform ZnO Nanosheet. Adv. Mater. 2005, 17, 586-590.

(47) Patil, G. P.; Baviskar, P. K.; Bagal, V. S.; Ladhe, R. D.; Deore, A. B.; More, M. A.; Sankapal, B. R.; Chavan, P. G. Aligned 2D CuSCN Nanosheets: a High Performance Field Emitter. RSC Adv. 2016, 6, 71958 .

(48) Vo, T.-G.; Chiu, J.-M.; Tai, Y.; Chiang, C.-Y. Turnip-inspired BiVO4/CuSCN nanostructure with close to $100 \%$ suppression of surface recombination for solar water splitting. Sol. Energy Mater. Sol. Cells 2018, 185, 415-424.

(49) Aldakov, D.; Chappaz-Gillot, C.; Salazar, R.; Delaye, V.; Welsby, K. A.; Ivanova, V.; Dunstan, P. R. Properties of electrodeposited CuSCN 2D layers and nanowires influenced by their mixed domain structure. J. Phys. Chem. C 2014, 118, 16095-16103.

(50) Li, K.; Wang, S.; Chen, C.; Kondrotas, R.; Hu, M.; Lu, S.; Wang, C.; Chen, W.; Tang, J. 7.5\% n-i-p Sb2Se3 solar cells with CuSCN as a holetransport layer. J. Mater. Chem. A 2019, 7, 96659672.

(51) Deo, M.; Shinde, D.; Yengantiwar, A.; Jog, J.; Hannoyer, B.; Sauvage, X.; More, M.; Ogale, S. $\mathrm{Cu}_{2} \mathrm{O} / \mathrm{ZnO}$ Hetero-nanobrush: Hierarchical Assembly, Field Emission and Photocatalytic Properties. J. Mater. Chem. 2012, 22, 17055-17062.

(52) Suryawanshi, S. R.; Mistari, C. D.; Singh, A. K.; Phase, D. M.; Late, D. J.; Sinha, S.; More, M. A. A Facile Approach towards Fabrication of GdB6-ZnO Heteroarchitecture as High Current Density Cold Cathode. ChemistrySelect 2016, 1, 3723-3729.

(53) Yin, H.; Song, C.; Wang, Z.; Guo, B.; Yu, K. V2O5 Nanoparticles Grown on $\mathrm{ZnO}$ Nanowires for Enhanced Field Emission Properties. Appl. Surf. Sci. 2015, 345, 256-263.

(54) Byeon, J. H.; Kim, J.-W. Aerosol Assisted Fabrication of Carbon Nanotube/Zinc Oxide Arrays for a Field Emission Device. J. Colloid Interface Sci. 2013, 393, 397.

(55) Warule, S. S.; Chaudhari, N. S.; Shisode, R. T.; Desa, K. V.; Kale, B. B.; More, M. A. Decoration of CdS Nanoparticles on 3D Selfassembled ZnO Nanorods: a Single-Step Process with Enhanced Field Emission Behavior. CrystEngComm 2015, 17, 140-148.

(56) Shisode, R. T.; Suryawanshi, S. R.; Mistari, C. D.; Late, D. J.; More, M. A. Enhanced Field Emission Characteristics of a 3D Hierarchical HfO2-ZnO Heteroarchitecture. ChemistrySelect 2017, 2, $2305-2310$

(57) Smith, D. L.; Saunders, V. I. Preparation and Structure Refinement of the $2 \mathrm{H}$ Polytype of $\beta$-copper(I) Thiocyanate. Acta Crystallogr., Sect. B: Struct. Sci. 1982, 38, 907-909.

(58) Özgür, Ü.; Alivov, Y. I.; Liu, C.; Teke, A.; Reshchikov, M. A.; Dogan, S.; Avrutin, V.; Cho, S. J.; Morkoc, H. A. A Comprehensive Review of $\mathrm{ZnO}$ Materials and Devices. J. Appl. Phys. 2005, 98, 041301.

(59) Krukau, A. V.; Vydrov, O. A.; Izmaylov, A. F.; Scuseria, G. E. Influence of the Exchange Screening Parameter on the Performance of Screened Hybrid Functionals. J. Chem. Phys. 2006, 125, 224106.

(60) Kresse, G.; Furthmüller, J.; Hafner, J. Theory of the Crystal Structures of Selenium and Tellurium: The Effect of Generalized- 
Gradient Corrections to the Local-Density Approximation. Phys. Rev. B: Condens. Matter Mater. Phys. 1994, 50, 13181-13185.

(61) Kresse, G.; Joubert, D. From Ultrasoft Pseudopotentials to the Projector Augmented-Wave Method. Phys. Rev. B: Condens. Matter Mater. Phys. 1999, 59, 1758-1775.

(62) Kresse, G.; Furthmüller, J. Efficient Iterative Schemes for ab initio Total-Energy Calculations using a Plane-Wave Basis set. Phys. Rev. B: Condens. Matter Mater. Phys. 1996, 54, 11169-11186.

(63) Jaffe, J. E.; Kaspar, T. C.; Droubay, T. C.; Varga, T.; Bowden, M. E.; Exarhos, G. J. Electronic and Defect Structures of CuSCN. J. Phys. Chem. C 2010, 114, 9111-9117.

(64) Tennakone, K.; Jayatissa, A. H.; Fernando, C. A. N.; Wickramanayake, S.; Punchihewa, S.; Weerasena, L. K.; Premasiri, W. D. R. Semiconducting and Photoelectroehemical Properties of $\mathrm{n}$ and p-Type P-CuCNS. Phys. Status Solidi 1987, 103, 491-497.

(65) Garnier, J.; Parize, R.; Appert, E.; Chaix-Pluchery, O.; Kaminski-Cachopo, A.; Consonni, V. Physical Properties of Annealed $\mathrm{ZnO}$ Nanowire/CuSCN Heterojunctions for Self-Powered UV Photodetectors. ACS Appl. Mater. Interfaces 2015, 7, 5820-5829.

(66) Kumara, G. R. R. A.; Konno, A.; Senadeera, G. K. R.; Jayaweera, P. V. V.; De Silva, D. B. R. A.; Tennakone, K. Dyesensitized solar cell with the hole collector $\mathrm{p}$-CuSCN deposited from a solution in n-propyl sulphide. Sol. Energy Mater. Sol. Cells 2001, 69, 195.

(67) Minami, T.; Miyata, T.; Yamamoto, T. Work Function of Transparent Conducting Multicomponent Oxide Thin Films Prepared by Magnetron Sputtering. Surf. Coat. Technol. 1998, 108109, 583-587.

(68) Baviskar, P. K.; Dubal, D. P.; Majumder, S.; Ennaoui, A.; Sankapal, B. R. Basic idea, Advance approach: Efficiency Boost by Sensitization of Blended dye on Chemically Deposited $\mathrm{ZnO}$ films. J. Photochem. Photobiol., A 2016, 318, 135-141.

(69) Baviskar, P. K.; Nikam, P. R.; Gargote, S. S.; Ennaoui, A.; Sankapal, B. R. Controlled Synthesis of $\mathrm{ZnO}$ Nanostructures with Assorted Morphologies via Simple Solution Chemistry. J. Alloys Compd. 2013, 551, 233-242.

(70) Baviskar, P. K. Low-cost Solid-State Dye-sensitized Solar Cell based on $\mathrm{ZnO}$ with $\mathrm{CuSCN}$ as a hole Transport Material using Simple Solution Chemistry. J. Solid State Electrochem. 2017, 21, 2699-2705.

(71) Ganesh, R. S.; Mani, G. K.; Elayaraja, R.; Durgadevi, E.; Navaneethan, M.; Ponnusamy, S.; Tsuchiya, K.; Muthamizhchelvan, C.; Hayakawa, Y. ZnO Hierarchical 3D-Flower Like Architectures and their Gas Sensing Properties at Room Temperature. Appl. Surf. Sci. 2018, 449, 314.

(72) Cao, F.; Li, C.; Li, M.; Li, H.; Huang, X.; Yang, B. Direct Growth of $\mathrm{Al}$-doped $\mathrm{ZnO}$ Ultrathin Nanosheets on Electrode for Ethanol Gas Sensor Application. Appl. Surf. Sci. 2018, 447, 173.

(73) Liu, H.; Li, M.; Wei, Y.; Liu, Z.; Hu, Y.; Ma, H. A Facile Surfactant-free Synthesis of Flower-like $\mathrm{ZnO}$ Hierarchical Structure at Room Temperature. Mater. Lett. 2014, 137, 300-303.

(74) Becker, M. A.; Radich, J. G.; Bunker, B. A.; Kamat, P. V. How Does a SILAR CdSe Film Grow? Tuning the Deposition Steps to Suppress Interfacial Charge Recombination in Solar Cells. J. Phys. Chem. Lett. 2014, 5, 1575-1582.

(75) Blöchl, P. E. Projector Augmented-Wave Method. Phys. Rev. B: Condens. Matter Mater. Phys. 1994, 50, 17953-17979.

(76) Monkhorst, H. J.; Pack, J. D. Special Points for Brillouin-zone Integrations. Phys. Rev. B: Condens. Matter Mater. Phys. 1976, 13, 5188.

(77) Perdew, J. P.; Burke, K.; Ernzerhof, M. Generalized Gradient Approximation Made Simple [Phys. Rev. Lett. 77, 3865 (1996)]. Phys. Rev. Lett. 1997, 78, 1396.

(78) Blöchl, P. E.; Jepsen, O.; Andersen, O. K. Improved Tetrahedron Method for Brillouin-Zone Integrations. Phys. Rev. B: Condens. Matter Mater. Phys. 1994, 49, 16223.

(79) Watson, G. W.; Kelsey, E. T.; de Leeuw, N. H.; Harris, D. J.; Parker, S. C. Atomistic Simulation of Dislocations, Surfaces and Interfaces in MgO. J. Chem. Soc., Faraday Trans. 1996, 92, 433-438.
(80) Tasker, P. W. The Stability of Ionic Crystal Surfaces. J. Phys. C: Solid State Phys. 1979, 12, 4977-4984.

(81) Walsh, A.; Butler, K. T. Prediction of Electron Energies in Metal Oxides. Acc. Chem. Res. 2013, 47, 364-372.

(82) Ganose, A. M.; Butler, K. T.; Walsh, A.; Scanlon, D. O. Relativistic Electronic Structure and Band Alignment of BiSI and BiSeI: Candidate Photovoltaic Materials. J. Mater. Chem. A 2016, 4, 2060-2068.

(83) Wu, L.; Dzade, N. Y.; Gao, L.; Scanlon, D. O.; Öztürk, Z.; Hollingsworth, N.; Weckhuysen, B. M.; Hensen, E. J. M.; de Leeuw, N. H.; Hofmann, J. P. Enhanced Photoresponse of $\mathrm{FeS}_{2}$ Films: The Role of Marcasite-Pyrite Phase Junctions. Adv. Mater. 2016, 28, 9602-9607. 